Hal : $63-73$

\title{
ANALISIS POLA BELANJA KONSUMEN MENGGUNAKAN ALGORITMA APRIORI PADA RAFFA PHOTOCOPY
}

\author{
Nurul Azwanti ${ }^{1}$, Nopriadi ${ }^{2}$ \\ 1,2Fakultas Teknik dan Komputer, Universitas Putera Batam \\ Jalan R. Soeprapto-Muka Kuning, Batam \\ nurulazw@rocketmail.com
}

\begin{abstract}
Every day there are sales transactions at Raffa Photocopy, where sometimes consumers do not just buy one item, but two items even more in one transaction. The recording of the transaction is kept as an archive only by Raffa Photocopy. One effort to increase sales at Raffa Photocopy can be done by processing transaction data that is piling up using associate data mining techniques. This association rule technique uses the Apriori algorithm which deals with studies finding patterns of association of items that are often purchased. The results of this study in the form of rules include the first, if you buy an eraser, it is likely that consumers also buy books simultaneously. Second, if you buy Tipex, then consumers also buy a double folio. The results of the Apriori algorithm process are based on a minimum support value of $35 \%$ and a minimum confidence value of $80 \%$. Based on the results obtained help Raffa Photocopy to always provide stock of goods that are often sold and the layout can be improved by placing adjacent items that are often sold together such as erasers, tipex and books.
\end{abstract}

Keywords: Combination, Pola, Apriori

\begin{abstract}
Abstrak
Setiap hari terjadi transaksi penjualan pada Raffa Photocopy, dimana terkadang konsumen tidak hanya membeli satu barang, melainkan dua barang bahkan lebih dalam satu transaksi. Pencatatan transaksi disimpan sebagai arsip saja oleh Raffa Photocopy. Salah satu upaya untuk meningkatkan penjualan pada Raffa Photocopy dapat dilakukan dengan cara mengolah data transaksi yang menumpuk dengan menggunakan data mining teknik asosiasi. Teknik aturan asosiasi ini menggunakan algoritma Apriori yang berkenaan dengan studi menemukan pola asosiasi barang-barang yang sering dibeli. Hasil dari penelitian ini berupa rules diantaranya adalah pertama, jika membeli penghapus, maka besar kemungkinan konsumen juga membeli buku tulis secara bersamaan. Kedua, jika membeli Tipex maka konsumen juga membeli double folio. Hasil dari proses algoritma Apriori ini didasarkan dari minimum nilai support $35 \%$ dan minimum nilai confidence $80 \%$. Berdasarkan dari hasil yang didapatkan membantu pihak Raffa Photocopy untuk selalu menyediakan stok barang yang sering terjual dan tata letak dapat diperbaiki dengan meletakkan berdekatan barang yang sering terjual bersamaan seperti penghapus, tipex dan buku tulis.
\end{abstract}

Kata Kunci: Kombinasi, Pola, Apriori

\section{PENDAHULUAN}

Membuka usaha merupakan salah satu peluang paling besar untuk bisa bertahan hidup di era perekonomian Indonesia saat ini, khususnya di kota Batam. Tercatat dari data Disnaker tahun 2015-2017 data pencari kerja mencapai 89.500 orang, sedangkan lowongan pekerjaan mulai dari tahun 2015-2017 hanya untuk 54.524 orang di Batam[1]. Rendahnya jumlah lowongan pekerjaan 
Hal : $63-73$

ini membuat para pencari kerja harus berfikir ulang untuk menyambung hidup dan tidak bisa mengandalkan hanya menjadi seorang karyawan atau pekerja saja. Adapun kegiatan untuk memulai usaha memang tidaklah mudah, selain resiko kegagalan yang tinggi juga membutuhkan modal dan skill dibidangnya. Tetapi, semua usaha bisa dimulai dari usaha kecil terlebih dahulu dan melihat pangsa pasar yang ada.

Jenis usaha dengan pangsa pasar yang menjanjikan adalah usaha fotocopy. Raffa Photocopy adalah salah satu toko yang memulai usahanya pada tahun 2016. Usaha ini tidak hanya menyediakan jasa fotocopy, namun juga menyediakan penjualan alat tulis kantor dan perlengkapan sekolah. Letaknya juga sangat strategis karena berdekatan dengan sekolah SD, SMP, SMA dan wilayah perumahan Cipta Asri Tahap 2 dan 3. Raffa Photocopy bukan satusatunya usaha fotocopy yang ada di wilayah tersebut, karena memiliki beberapa pesaing dari jenis usaha yang sama. Banyak faktor yang dapat membuat usaha fotocopy tetap bertahan diantaranya lokasi yang strategis, mesin fotocopy yang tepat, pengelolaan usaha yang bagus, harga jual perlembar yang kompetitif, pelayanan yang cepat dan memuaskan. Namun, seperti kebalikannya, tidak sedikit pula usaha fotocopy harus gulung tikar karena tidak memperhatikan beberapa faktor penting diantaranya seperti pelayanan yang kurang memuaskan [2].

Pada proses penjualan alat tulis kantor dan perlengkapan sekolah di Raffa Photocopy setiap harinya terjadi pencatatan barang yang terjual. Barang yang terjual tersebut memiliki keterkaitan antara satu dengan yang lain, karena dalam pencatatannya terkadang konsumen tidak hanya membeli satu barang, melainkan dua barang bahkan lebih seperti halnya ketika membeli buku, besar kemungkinan konsumen juga membeli pulpen. Pencatatan ini hanya disimpan sebagai arsip saja, padahal banyaknya transaksi penjualan yang terjadi setiap hari bisa menimbulkan adanya tumpukan data. Salah satu upaya untuk meningkatkan penjualan pada Raffa Photocopy dapat dilakukan dengan cara mengolah data transaksi yang menumpuk tersebut menjadi sebuah informasi yang berguna. Informasi yang berguna dapat dimanfaatkan menjadi sebuah strategi bisnis [3].

Metode dalam mengolah tumpukan data menjadi informasi adalah metode data mining. Data mining juga memiliki berbagai teknik untuk melakukan asosisasi, clustering maupun klasfikasi. Pada kasus Raffa Photocopy, dibutuhkan teknik aturan asosiasi dengan melakukan analisis suatu transaksi penjualan. Analisis transaksi penjualan ini bertujuan untuk merancang strategi penjualan atau pemasaran yang efektif dengan memanfaatkan data transaksi penjualan yang telah tersedia [4]. Teknik aturan asosiasi ini menggunakan algoritma Apriori yang berkenaan dengan studi tentang 'apa bersama apa' atau menemukan pola asosiasi barang-barang yang sering dibeli bersamaan atau produk yang cenderung muncul bersama dalam sebuah transaksi [5]. Pihak Raffa Photocopy dapat menggunakan pola ini untuk menempatkan produk yang sering dibeli ke dalam sebuah area yang berdekatan guna meningkatkan pendapatannya.

\section{TINJAUAN PUSTAKA}

\subsection{Knowledge Discovery in Databases (KDD)}

Penambangan data juga disebut Knowledge Discovery in Database (KDD) didefinisikan sebagai ekstraksi informasi potensial, implisit dan tidak diketahui dari kumpulan data. Proses Knowlegde Discovery dalam database melibatkan hasil dari proses penambangan data (proses 
Hal : $63-73$

mengekstraksi tren pola data), kemudian mengubah hasilnya secara akurat menjadi informasi yang dapat dimengerti[6].

Istilah penggalian data dan penemuan pengetahuan dalam basis data (KDD) sering digunakan secara bergantian untuk menggambarkan proses penggalian informasi tersembunyi pada sebuah database besar. Sebenarnya istilah tersebut memiliki konsep yang berbeda, tetapi saling terkait satu sama lain. Salah satu tahapan dalam seluruh proses KDD adalah data mining [7].

\subsection{Data Mining}

Penambangan data merupakan teknik untuk mendapatkan informasi bernilai yang disembunyikan atau tersembunyi dalam database yang sangat besar atau dalam tumpukan data, sehingga pola yang menarik yang sebelumnya tidak diketahui ditemukan. Penambangan data itu sendiri berarti upaya untuk mendapatkan beberapa barang berharga dari serangkaian bahan dasar. Penambangan data sebenarnya memiliki akar panjang di bidang-bidang seperti kecerdasan buatan (artificial intelligence), pembelajaran mesin, statistik, dan basis data [8].

\subsection{Analisis asosiasi}

Analisis Asosiasi Penambangan atau aturan asosiasi penambangan adalah teknik penambangan data untuk menemukan aturan hubungan antara kombinasi elemen. Contoh aturan kemitraan dari analisis pembelian di supermarket adalah untuk mengetahui seberapa besar kemungkinan seseorang membeli roti beserta susu. Berdasarkan pengetahuan ini, supermarket dapat mengatur penempatan produk mereka atau merancang kampanye pemasaran dengan menggunakan kupon diskon untuk kombinasi tertentu dari produk data itu sendiri berarti upaya untuk mendapatkan beberapa barang berharga dari sejumlah bahan dasar [9].

Analisis terkait juga dikenal sebagai teknik yang membentuk dasar dari berbagai teknik penambangan data, terutama salah satu tahapan dalam analisis asosiasi yang disebut analisis pola frekuensi tinggi yang menarik perhatian untuk menghasilkan algoritma yang efisien. Pentingnya aturan asosiatif dapat ditentukan oleh dua parameter, yaitu, dukungan dan kepercayaan. Dukungan adalah persentase kombinasi elemen dalam database, sedangkan kepercayaan adalah hubungan yang kuat antara elemen-elemen dalam aturan asosiatif. Karena analisis asosiasi terkenal dengan aplikasinya untuk menganalisis isi keranjang belanja di supermarket, analisis asosiasi juga dikenal sebagai analisis keranjang [8].

\subsection{Algoritma Apriori}

Algoritma apriori adalah jenis aturan asosiasi pada data mining. Algoritma ini ditujukan untuk mencari kombinasi itemset yang mempunyai suatu nilai keseringan tertentu sesuai kriteria atau filter yang diinginkan (Kusrini dan Luthfi, 2009) dalam [10]. Algoritma ini diajukan oleh R. Agrawal dan R. Srikant tahun 1994.

Menurut (Kusrini dan Luthfi, 2009) dalam [11], Metodologi dasar analisis asosiasi terbagi menjadi dua tahap :

1. Analisa pola frekuensi tinggi

Tahap ini mencari kombinasi item yang memenuhi syarat minimum dari nilai support dalam database. Nilai support sebuah item diperoleh dengan rumus berikut:

Support $(A)=\frac{\text { Jumlah transaksi mengandung A }}{\text { Total Transaksi }}$ 
Hal : $63-73$

Menghitung nilai 1(satu) item support

Sedangkan nilai support dari 2 item diperoleh dari rumus 2 berikut.

Support $(A, B)=\frac{\sum \text { Jumlah transaksi mengandung } A \text { dan } B}{\sum \text { Total Transaksi }}$

Menghitung nilai 2 (dua) item support

2. Pembentukan Aturan Asosiasi

Pembentukan Aturan Asosiasi Setelah semua pola frekuensi tinggi ditemukan, barulah dicari aturan asosiasi yang memenuhi syarat minimum untuk confidence dengan menghitung confidence aturan asosiasif " jika A maka B ". Nilai confidence dari aturan "jika A maka B " diperoleh dari rumus berikut.

Confidence $\mathrm{P}(\mathrm{B} \mid \mathrm{A})=\frac{\sum \text { Jumlah transaksi mengandung A dan } \mathrm{B}}{\sum \text { Transaksi mengandung A }}$

Menghitung confidence aturan asosiasif

Algoritma apriori dibagi menjadi beberapa tahap yang disebut narasi atau pass [12], yaitu :

1. Pembetukan kandidat itemset

Kandidat k-itemset dibentuk dari kombinasi (k-1)-itemset yang didapt dari iterasi sebelumnya. Satu cara dari algoritma apriori adalah pemangkasan kandidat k-itemset yang subsetnya berisi k-1 item tidak termasuk dalam pola frekuensi tinggi dengan panjang $\mathrm{k}-1$.

2. Penghitungan support dari tiap kandidat k-itemset. Support dari tiap kandidat k-itemset didapat dengan menscan database untuk mengitung jumlah transaksi yang memuat semua item didalam kandidat k-itemset tersebut. Ini adalah juga ciri dari algoritma apriori dimana diperlukan penghitungan dengan cara seluruh database sebanyak k-itemset terpanjang

3. Tetapkan pola frekuensi tinggi. Pola frekuensi tinggi yang memuat $\mathrm{k}$ item atau $\mathrm{k}$ itemset ditetapkan dari kandidat dari k-itemset yang supportnya lebih besar dari minimum support.

4. Bila tidak didapat pola frekuensi tinggi baru maka seluruh proses dihentikan. Bila tidak, maka k ditambah satu dan kembali bagian 1 .

\section{METODE PENELITIAN}

Adapun bentuk desain penelitian dapat digambarkan pada gambar 1 berikut :

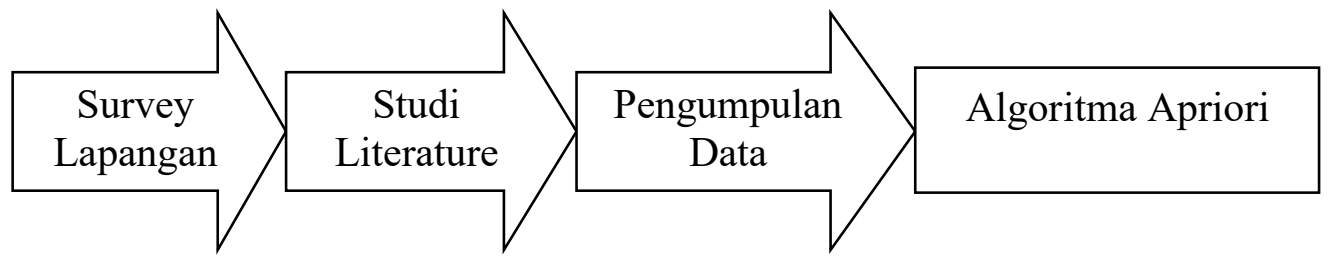

Gambar 1. Desain Penelitian

Berdasarkan gambar 1 di atas, masing-masing langkahnya diuraikan sebagai berikut:

1. Survey lapangan 
Hal : $63-73$

Tahap awal dari penelitian ini adalah melakukan survey ke lokasi tempat penelitian yakni berada di Jl. Trans Barelang, Tembesi, Sagulung, Kota Batam, Kepulauan Riau 29472 tepatnya Ruko Cipta Asri Boulevard B No. 03.

2. Studi Literature

Pada tahap ini melakukan studi pustaka mencari jurnal dan penelitian terdahulu.

3. Pengumpulan data

Data yang terkumpul adalah data penjualan seperti gambar 3 dengan 14 transaksi dan 12 item.

\begin{tabular}{|c|c|c|c|c|c|c|c|}
\hline Transalksi & & & Iten & 1 yang dijual & & & \\
\hline 1 & Pulpen & Pensil & $\begin{array}{l}\text { Buku } \\
\text { Tulis }\end{array}$ & Double Folio & Tipex & & \\
\hline 2 & Tipex & $\begin{array}{l}\text { Double } \\
\text { Folio }\end{array}$ & & I & & & \\
\hline 3 & Buku Tulis & Tipex & Amplop & & & & \\
\hline 4 & Spidol & Penggaris & Lakban & & & & \\
\hline 5 & Buku Tulis & Pensil & Penggaris & Penghspus & & & \\
\hline 6 & Spidol & Penghapus & Pensil & & & & \\
\hline 7 & Stabilo & Penggaris & $\begin{array}{l}\text { Buku } \\
\text { Tulis }\end{array}$ & & & & \\
\hline 8 & Lakban & Spidol & & & & & \\
\hline 9 & Buku Tulis & $\begin{array}{l}\text { Double } \\
\text { Folio }\end{array}$ & Penghapus & Amplop & Penggaris & & \\
\hline 10 & Bukzu Tulis & Pulpen & Lakban & Penghapus & Amplop & & \\
\hline 11 & Buks Tulis & Spidol & Pulpen & Tipex & $\begin{array}{l}\text { Double } \\
\text { Folio }\end{array}$ & & \\
\hline 12 & Pensil & $\begin{array}{l}\text { Double } \\
\text { Folio }\end{array}$ & Amplop & Pulpen & $\begin{array}{l}\text { Buku } \\
\text { Tulis }\end{array}$ & Tipex & Penghspus \\
\hline 13 & Buku Tulis & Pensil & Penghspus & & & & \\
\hline 14 & Pulpen & Crayon & Tipex & Double Folio & Crayon & Pensil & \\
\hline
\end{tabular}

Gambar 2. Item yang terjual

4. Algoritma Apriori

Penerapan algoritma apriori akan menemukan pola dari pembelian konsumen berdasarkan pengolahan data penjualan pada hasil dan pembahasan.

\section{HASIL DAN PEMBAHASAN}

Berdasarkan dari transaksi yang ada, diambil 14 sampel untuk dilakukan perhitungan menggunakan apriori.

\section{Pemilihan Item}

Mengacu pada tabel transaksi sebelumnya, maka dipilih masing-masing item untuk dilakukan pengkodean seperti pada tabel 1 .

\section{Tabel 1.Tabel Representasi Transaksi}

\begin{tabular}{cl}
\hline Kode Transaksi & \multicolumn{1}{c}{ Item } \\
\hline 1 & Pulpen \\
2 & Pensil \\
3 & Stabilo \\
4 & Buku Tulis
\end{tabular}


Hal : $63-73$

\section{Tabulasi Data Transaksi}

\begin{tabular}{cl}
5 & Crayon \\
6 & Penghapus \\
7 & Tipex \\
8 & Penggaris \\
9 & Amplop \\
10 & Lakban \\
11 & Spidol \\
12 & Double Folio \\
\hline
\end{tabular}

Pada tabel 1 data transaksi yang akan diolah akan diubah ke dalam bentuk tabel tabular yang berguna untuk mempermudah mengetahui berapa banyak item yang dibeli dalam setiap transaksi seperti pada gambar 4 berikut.

\begin{tabular}{|c|c|c|c|c|c|c|c|c|c|c|c|c|}
\hline Trans. & Pulpen & Pensil & Stabilo & $\begin{array}{c}\text { Buku } \\
\text { Tulis }\end{array}$ & Crayon & Penghapus & Tipex & Penggaris & Amplop & Lakban & Spidol & $\begin{array}{c}\text { Double } \\
\text { Folio }\end{array}$ \\
\hline 1 & 1 & 1 & 0 & 1 & 0 & 0 & 1 & 0 & 0 & 0 & 0 & 1 \\
\hline 2 & 0 & 0 & 0 & 0 & 0 & 0 & 1 & 0 & 0 & 0 & 0 & 1 \\
\hline 3 & 0 & 0 & 0 & 1 & 0 & 0 & 1 & 0 & 1 & 0 & 0 & 0 \\
\hline 4 & 0 & 0 & 0 & 0 & 0 & 0 & 0 & 1 & 0 & 1 & 1 & 0 \\
\hline 5 & 0 & 1 & 0 & 1 & 0 & 1 & 0 & 1 & 0 & 0 & 0 & 0 \\
\hline 6 & 0 & 1 & 0 & 0 & 0 & 1 & 0 & 0 & 0 & 0 & 1 & 0 \\
\hline 7 & 0 & 0 & 1 & 1 & 0 & 0 & 0 & 1 & 0 & 0 & 0 & 0 \\
\hline 8 & 0 & 0 & 0 & 0 & 0 & 0 & 0 & 0 & 0 & 1 & 1 & 0 \\
\hline 9 & 0 & 0 & 0 & 1 & 0 & 1 & 0 & 1 & 1 & 0 & 0 & 1 \\
\hline 10 & 1 & 0 & 0 & 1 & 0 & 1 & 0 & 0 & 1 & 1 & 0 & 0 \\
\hline 11 & 1 & 0 & 0 & 1 & 0 & 0 & 1 & 0 & 0 & 0 & 1 & 1 \\
\hline 12 & 1 & 1 & 0 & 1 & 0 & 1 & 1 & 0 & 1 & 0 & 0 & 1 \\
\hline 13 & 0 & 1 & 0 & 1 & 0 & 1 & 0 & 0 & 0 & 0 & 0 & 0 \\
\hline 14 & 1 & 1 & 0 & 0 & 1 & 0 & 1 & 0 & 0 & 0 & 0 & 1 \\
\hline Jumlah & $\mathbf{5}$ & $\mathbf{6}$ & $\mathbf{1}$ & $\mathbf{9}$ & $\mathbf{1}$ & $\mathbf{6}$ & $\mathbf{6}$ & $\mathbf{4}$ & $\mathbf{4}$ & $\mathbf{3}$ & $\mathbf{4}$ & $\mathbf{6}$ \\
\hline
\end{tabular}

Gambar 4.Tabulasi Item yang terjual

Angka 1 pada isian tabulasi di atas merupakan simbol bahwa barang atau item tersebut dibeli pada urutan transaksi.Sementara, angka 0 adalah kebalikannya yaitu barang atau item tersebut tidak dibeli.

\section{Pembentukan Itemset}

Adapun langkah-langkah dalam pembentukan itemset adalah sebagai berikut:

1. 1 Itemset

Berikut ini adalah penyelesaian berdasarkan data yang sudah disediakan pada tabel 5.3. Proses pembentukan $\mathrm{C} 1$ atau disebut dengan 1 itemset dengan jumlah menggunakan rumus (1) seperti perhitungan berikut ini: 

a. $\operatorname{Support}($ Pulpen $)=\frac{5}{14}=0.357$
b. $\operatorname{Support}($ Pensil $)=\frac{6}{14}=0.429$
c. $\operatorname{Support}($ Stabilo $)=\frac{1}{14}=0.071$
d. Support(Buku Tulis) $=\frac{9}{14}=0.643$
e. $\operatorname{Support}$ (Crayon) $=\frac{1}{14}=0.071$
f. Support(Penghapus) $=\frac{6}{14}=0.429$
g. Support(Tipex) $=\frac{6}{14}=0.429$
h. $\operatorname{Support}($ Penggaris $)=\frac{4}{14}=0.286$
i. $\operatorname{Support}\left(\right.$ Amplop) $=\frac{3}{14}=0.286$
j. $\quad$ Support (Lakban) $=\frac{4}{14}=0.214$
k. Support(Spidol $)=\frac{6}{14}=0.286$
1. Support (Double Folio) $=\frac{6}{14}=0.429$

Hasil dari perhitungan diatas diubah kedalam bentuk persentase untuk mengetahui confidence dari masing-masing item penjualan.

\section{Kombinasi 2 Itemset}

Proses pembentukan C2 atau disebut dengan 2 itemset dengan rumus (2), dapat dilihat pada tabel dibawah ini.

Tabel 2. Tabel Kombinasi 2itemset

\begin{tabular}{ccc}
\hline \multicolumn{2}{c}{ Nama Item Set } & Jumlah \\
\hline Buku Tulis & Pulpen & 4 \\
Buku Tulis & Pensil & 4 \\
Buku Tulis & Stabilo & 1 \\
Buku Tulis & Penghapus & 5 \\
Buku Tulis & Tipex & 4 \\
Buku Tulis & Penggaris & 3 \\
Buku Tulis & Amplop & 4 \\
Buku Tulis & Lakban & 1 \\
Buku Tulis & Spidol & 1 \\
Buku Tulis & Double Folio & 4 \\
Pensil & Pulpen & 3 \\
Pensil & Penghapus & 4 \\
Pensil & Crayon & 1 \\
Pensil & Penggaris & 1
\end{tabular}




\begin{tabular}{ccc} 
Pensil & Amplop & 1 \\
Pensil & Spidol & 2 \\
Pensil & Double Folio & 3 \\
Penghapus & Pulpen & 1 \\
Penghapus & Tipex & 1 \\
Penghapus & Penggaris & 2 \\
Penghapus & Amplop & 3 \\
Penghapus & Lakban & 1 \\
Penghapus & Spidol & 1 \\
Penghapus & Double Folio & 2 \\
Tipex & Pulpen & 2 \\
Tipex & Crayon & 1 \\
Tipex & Amplop & 2 \\
Tipex & Spidol & 1 \\
Tipex & Double Folio & 5 \\
Double Folio & Pulpen & 4 \\
Double Folio & Crayon & 1 \\
Double Folio & Penggaris & 1 \\
Double Folio & Amplop & 2 \\
Double Folio & Spidol & 1 \\
\hline & &
\end{tabular}

Dari tabel tersebut di atas, ditetapkan nilai $\varnothing=5$ sehingga yang dapat menjadi kombinasi 2 itemset adalah C2 $=\{($ Buku Tulis, Penghapus), (Tipex,Double Folio) $\}$.

\section{Pembetukan Aturan Assosiasi}

Setelah semua pola frekuensi tinggi ditemukan, kemudian dicari aturan asosiasi yang memenuhi syarat minimum untuk confidence dengan menghitung confidence aturan asosiatif $\boldsymbol{A} \rightarrow \boldsymbol{B}$, nilai confidence dari aturan $\boldsymbol{A} \rightarrow \boldsymbol{B}$.

Tabel 3. Kombinasi 2 itemset

\begin{tabular}{lr}
\hline \multicolumn{1}{c}{ Rule } & Confidence \\
\hline Jika beli Buku Tulis maka beli Penghapus & $56 \%$ \\
Jika beli Penghapus maka beli Buku Tulis & $\mathbf{8 3 \%}$ \\
Jika beli Tipex maka beli Double Folio & $\mathbf{8 3 . 3 3 \%}$ \\
Jika beli Double Folio maka beli Tipex & $\mathbf{8 3 . 3 3 \%}$ \\
\hline
\end{tabular}


Hal : $63-73$

Kemudian ditentukan bahwa untuk nilai confidence adalah minimum $80 \%$, maka hasil akhir rule yang dihasilkan adalah sebagai berikut.

Tabel 4.Final rule

\begin{tabular}{lr}
\hline \multicolumn{1}{c}{ Rule } & Confidence \\
\hline Jika beli Penghapus maka beli & \\
$\begin{array}{l}\text { Buku Tulis } \\
\text { Jika beli Tipex maka beli }\end{array}$ & $83 \%$ \\
$\begin{array}{l}\text { Double Folio } \\
\text { Jika beli Double Folio maka } \\
\text { beli Tipex }\end{array}$ & $83.33 \%$ \\
\hline
\end{tabular}

\section{Hasil Pengujian}

Pola kombinasi antar item yang telah dihasilkan dari perhitungan manual membentuk rules asosiasi sesuai dengan perhitungan algoritma apriori. Untuk menguji kebenarannya, maka diperlukan pengujian menggunakan software. Langkahnya adalah dengan menginputkan nilai support dan confidece.

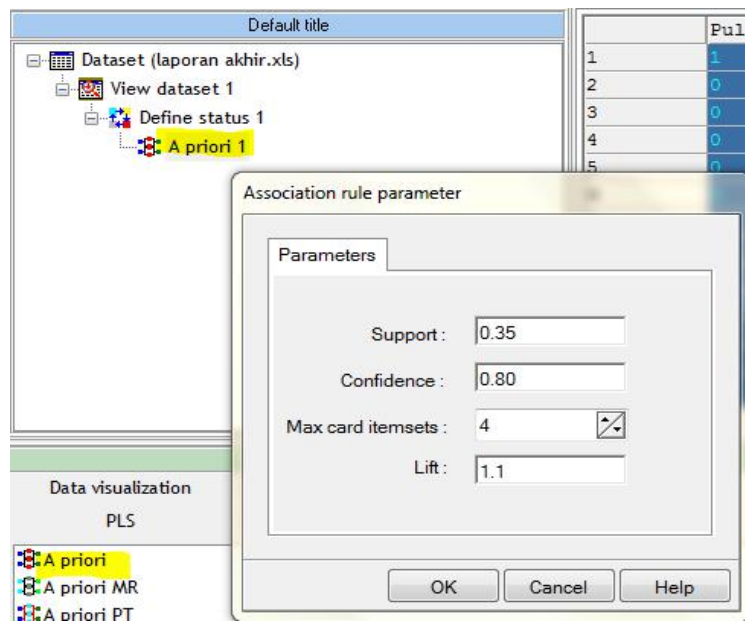

Gambar 5.Tampilan Association rule parameter 
Setelah dilakukan penentuan nilai parameters, maka rules-rules yang dihasilkan dari parameters diatas adalah seperti pada gambar dibawah ini.

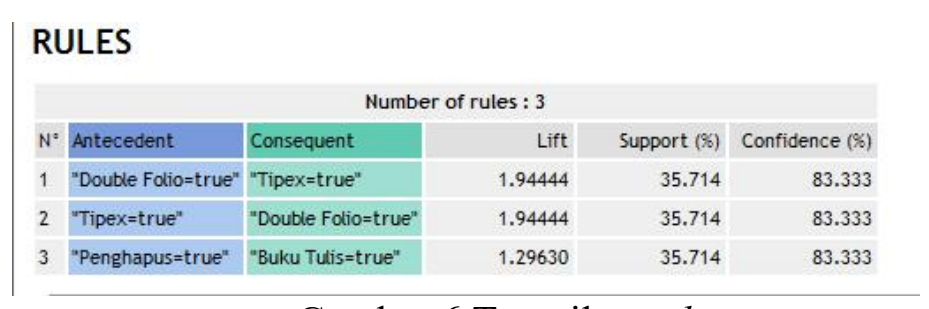

Gambar 6.Tampilan rules

Adapun rule yang dihasilkan tersebut memiliki hasil yang sama dari perhitungan manual yang telah dilakukan, diantaranya:

a. Jika beli DoubleFolio maka membeli Tipex

b. Jika beli Tipex maka membeli Double Folio

c. Jika beli Penghapus maka membeli Buku Tulis

\section{SIMPULAN}

Hasil dari ini didapat simpulan sebagai berikut:

1. Algoritma apriori sangat berguna untuk mengetahui hubungan dan kombinasi item yang paling diminati oleh konsumen, sehingga dapat dijadikan sebagai informasi yang berharga oleh pihak Raffa Photocopy untuk mengambil keputusan.

2. Berdasarkan dari hasil penelitian, dengan support $35 \%$ dan confidence $80 \%$ barang yang laku adalah Double Folio, Tipex, Penghapus dan Buku Tulis.

3. Hasil pengujian yang dilakukan menggunakan Tanagra menunjukkan hasil yang sama dari perhitungan manual, sehingga pengujian yang dilakukan sangat baik.

\section{UCAPAN TERIMAKASIH}

Terima kasih peneliti ucapkan kepada Dikti atas Hibah Penelitian Dosen Pemula dan LPPM Universitas Putera Batam.

\section{DAFTAR PUSTAKA}

[1] A. Simamora, "Pengangguran Makin Banyak di Batam. Jumlah Pencari Kerja Capai 89.500 Orang," tribunbatam.id, 2018.

[2] E. C. N. Gilang Gemilang Wahyu Aji Wijaya, "Sistem Informasi Toko Alat Tulis dan Fotocopy Bengawan," J. Ilm. GO INFOTECH, vol. 19, no. 1, pp. 14-20, 2013.

[3] I. Oktana and S. Hansun, "Penerapan Algoritma C4.5 pada Analisis Kerusakan Barang Jadi ( Studi Kasus : PT Kayu Lapis Asli Murni )," Ultim. Comput., vol. VII, no. 1, 2015.

[4] Hapsari Dita Anggraeni, Ragil Saputra, and Beta Noranita Ilmu, "Aplikasi Data Mining Analisis Data Transaksi Penjualan Obat Menggunakan Algoritma Apriori (Studi Kasus di Apotek Setya Sehat Semarang)," Masy. Inform., vol. 4, no. 7, pp. 1-8, 2012.

[5] E. S. Sihombing, A. S. Honggowibowo, and D. Nugraheny, "Implementasi Data Mining Menggunakan Metode Apriori Pada Transaksi Penjualan Barang (Studi Kasus Di Chorus Minimarket)," Compiller, vol. 1, no. 1, pp. 17-30, 2012.

[6] P. Informatika and B. Darma, "APLIKASI DATA MINING UNTUK MENAMPILKAN TINGKAT KELULUSAN MAHASISWA DENGAN 
ALGORITMA APRIORI," no. 911536, pp. 56-61, 2014.

[7] M. Le Cam, A. Daoud, and R. Zmeureanu, "Forecasting electric demand of supply fan using data mining techniques," Energy, vol. 101, pp. 541-557, 2016.

[8] W. Pramusinto, W. Budi, and U. Gunawan, "Implementasi Algoritma Apriori untuk Aplikasi Data Mining Informasi Manfaat Asuransi Jiwa Studi Kasus : Pada PT Azarel Jelia Sejahtera," TICOM, vol. 2, no. 1, pp. 43-50, 2013.

[9] H. Santoso, I. P. Hariyadi, and Prayitno, "Data Mining Analisa Pola Pembelian Produk dengan Menggunakan Metode Algoritma Apriori," Semin. Nas. Teknol. Inf. dan Multimed. 2016, pp. 19-24, 2016.

[10] H. D. Hutahaean, B. Sinaga, and A. A. Rajagukguk, "Analisa Dan Perancangan Aplikasi Algoritma Apriori Untuk Korelasi Penjualan Produk ( Studi Kasus : Apotik Diory Farma )," JIPN (Journal Informatics Pelita Nusantara), vol. 1, no. 1, pp. 7-13, 2016.

[11] Nurdin and D. Astika, "Penerapan Data Mining Untuk Menganalisis Penjualan Barang Dengan Pada Supermarket Sejahtera Lhokseumawe," Techsi, vol. 6, no. 1, pp. 134-155, 2015.

[12] Nurjoko and A. Darmawan, "Penerapan data mining menggunakan association rules untuk mendukung strategi pemasaran calon mahasiswa baru (studi kasus ibi darmajaya)," J. TIM Darmajaya, vol. 1, no. 1, pp. 17-32, 2015. 